\title{
Pengaruh Mutagen Kimia EMS terhadap Perkembangan Bunga Tanaman Cabai (Capsicum frutescens var. bara)
}

\author{
Andriyani dan Wirdhatul Muslihatin \\ Departemen Biologi, Fakultas Ilmu Alam, Institut Teknologi Sepuluh Nopember (ITS) \\ e-mail: w_muslih@bio.its.ac.id
}

\begin{abstract}
Abstrak-Peningkatan produktivitas cabai rawit (Capsicum frutescens var. bara) dapat dilakukan melalui variasi genetik menggunakan mutagen kimia EMS (Etil Metan Sulfonat). Bunga merupakan organ reproduksi angiospermae yang setelah bunga masak, akan terjadi penyerbukan dan pembuahan sehingga terbentuklah buah yang berisi biji. Penelitian ini dilakukan untuk mengetahui pengaruh EMS terhadap perkembangan bunga tanaman cabai vaietas bara. Hasil penelitian menunjukkan adanya pengaruh EMS 0,5\% terdahadap morfologi bunga yakni terdapat satu individu yang diduga menghasilkan bunga mutan. Bunga yang diduga mutan tidak memiliki organ bunga lengkap dan berbentuk bulat.
\end{abstract}

Kata Kunci-Bunga, Cabai, EMS, Mutasi.

\section{PENDAHULUAN}

$\mathrm{C}$ ABAI merupakan tanaman yang memiliki nilai ekonomi yang tinggi [1]. Pada tahun 2002-2013 penggunaan cabai untuk bahan makanan cenderung meningkat sebasar $11,14 \%$ per tahun [2]. Kenaikan kebutuhan cabai tidak diimbangi dengan kenaikan produktivitas. Pada tahun 2014 produktivitas tanaman cabai mengalami penurunan sebesar $42,20 \%$ dari tahun sebelumnya [3]. Panen cabai sangat dipengaruhi oleh faktor lingkungan tumbuh dan varietas [4].

Upaya peningkatan produktivitas tanaman dapat dilakukan dengan meningkatkan variasi genetik [5]. Bunga merupakan organ reproduksi angiospermae. Bunga dibentuk oleh meristem pucuk khusus, berkembang dari ujung batang, setelah bunga masak, akan terjadi penyerbukan dan pembuahan sehingga terbentuklah buah yang berisi biji [6].

Penggunaan radiasi serta mutagen kimiawi untuk menginduksi variasi pada tanaman telah banyak dilakukan [7]. Etil Metan Sulfonat (EMS) adalah mutagen kimia yang banyak digunakan untuk memperluas keragaman genetik pada tanaman untuk tujuan pemuliaannya. Peningkatan keragaman genetik tanaman dengan induksi EMS telah berhasil dilakukan pada berbagai spesies tanaman [8]. EMS (Ethyl metanosulfonate; $\mathrm{CH}_{3} \mathrm{SO}_{2} \mathrm{OC}_{2} \mathrm{H}_{5}$ ) merupakan mutagen yang efektif dan efisisen. EMS memiliki berat molekul $124 \mathrm{~g} / \mathrm{mol}$. Senyawa ini memiliki satu atau lebih gugus alkil yang reaktif yang dapat di transfer ke molekul lain [9]. EMS (Etil Metan Sulfonat) merupakan senyawa alkil yang mengubah guanin menjadi 7-etilguanin yang berpasangan dengan timin [10].

Penelitian dilakukan untuk mengetahui pengaruh EMS terhadap perkembangan bunga tanaman cabai (Capsicum frutescens var. bara) [11].

\section{METODOLOGI}

\section{A. Waktu dan Tempat Penelitian}

Penelitian ini dilaksanakan pada bulan Desember 2016- Mei 2017. Penelitian ini dilakukan pada dua lokasi yakni di Lahan yang berlokasi di Desa Mentaras Kabupaten Gresik dan laboratorium Biosains dan Teknologi tumbuhan Biologi ITS.

\section{B. Tahap Persiapan}

1. Perendaman benih cabai dalam medium EMS

Benih direndam dalam air selama $3 \mathrm{jam}$, benih yang tenggelam diambil dan direndam pada larutan EMS konsentrasi $0,5 \%, 1 \%, 1,5 \%$ dan $2 \%$ selama 6 jam, setiap konsentrasi berisi 100 benih, kemudian benih dikeringkan diatas kertas saring. Benih pada perlakuan kontrol direndam menggunakan larutan aquades.

2. Persiapan Media tanam

Media tanam disiapkan dengan mencampurkan $1 \mathrm{~kg}$ tanah, $0,5 \mathrm{~kg}$ pupuk kandang dan $0,5 \mathrm{~kg}$ sekam. Media tanam kemudian diaduk hingga semua bahan tercampur rata. Ukuran media tanam tersebut merupakan takaran media untuk satu polybag ukuran $3 \mathrm{Kg}$. Media tanam tersebut kemudian ditambahkan pupuk NPK sebanyak 5 gram / polybag [12].

\section{Penyemaian dan Pemeliharaan Tanaman Cabai}

Penyemaian benih dilakukan dengan memepersiapkan media semai dalam bak, komposisi media semai yakni $1 \mathrm{~kg}$ tanah, 0,5 kg sekam dan 0,5 kg pupuk. Media semai kemudian di aduk rata dan benih cabai ditanam sedalam $0,5 \mathrm{~cm}$ dalam media tersebut. Benih disiram sebanyak 1 kali sehari yakni sore hari, benih kemudian dirawat hingga tumbuh bibit cabai yang memiliki 2 daun [13].

4. Analisa Data

Penelitian dilakukan dengan Rancangan Acak Lengkap (RAL) satu faktor yaitu konsentrasi EMS. Pengulangan dalam penelitian ini dilakukan sebanyak 6 kali. Data yang dihasilkan akan dianalisa secara deskriptif kualitatif.

\section{PEMBAHASAN}

Bunga cabai merupakan bunga yang tumbuh tunggal dari ketiak-ketiak daun dan ujung ruas. Struktur bunga mempunyai 5-6 helai mahkota, 5 helai daun bunga, 1 putik (stigme) dengan kepala putik berbentuk bulat, 5-8 helai benang sari dengan kepala sari berbentuk lonjong dan berwarna biru keunguan [4] Bunga cabai varietas bara pada konsentrasi EMS yang berbeda memiliki morfologi yang sama dengan bunga cabai tanaman kontrol (Gambar 1). 


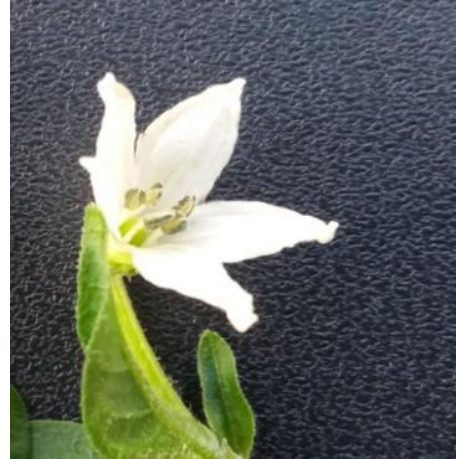

Gambar 1. Morfologi bunga cabai normal.

Bunga tanaman cabai pada semua perlakuan menunjukkan morfologi yang sama yakni memiliki 5 helai mahkota, 1 putik, 5 kelopak, 5 benang sari yang berbentuk lonjong dan berwarna ungu kebiruan, namun terdapat 1 individu memiliki bunga yang di duga mutan (Gambar 2).

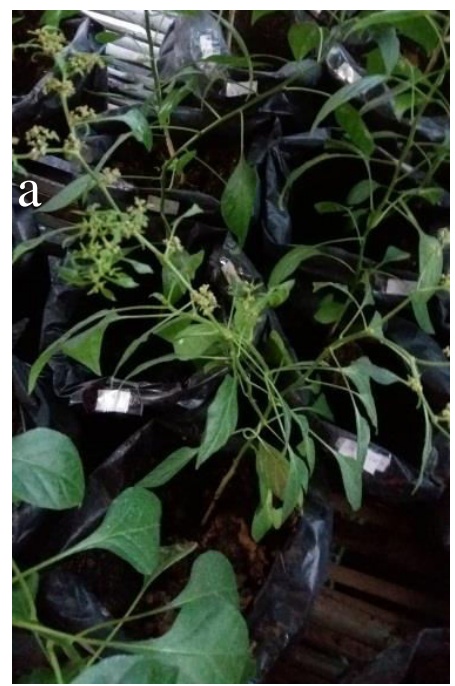

Gambar 2. Tanaman yang diduga memiliki bunga mutan Keterangan: a. bunga yang di duga mutan.

Tanaman yang diduga memiliki bunga mutan memiliki morfologi tanaman yang sama dengan tanaman cabai varietas bara yang lain, namun tinggi tanaman cenderung lebih pendek. Tanaman yang memiliki bunga mutan merupakan tanaman pada konsentrasi EMS 0,5\%. Bunga yang diduga mutan memiliki morfologi bunga yang berbeda dengan bunga cabai varietas bara yang lain (Gambar 3).

Bunga yang diduga mutan dihasilkan pada perlakuan EMS $0,5 \%$. Bunga tersebut memiliki bentuk bulat, berwarna hijau, bergerombol dan tidak memiliki bagian-bagian bunga seperti benang sari, putik, kelopak dan mahkota bunga. Morfologi ini berbeda dengan morfologi bunga cabai bara normal.

Terdapat tiga kelas gen yang berpengaruh pada perkembangan organ identitas bunga yakni gen kelas A, gen kelas B dan gen kelas C. Kondisi tidak terbentuknya organ bunga kemungkinan terjadi karena adanya mutasi pada gen kelas A, gen kelas B maupun gen kelas C. Mutasi titik yang diinduksi oleh EMS memiliki pengaruh pada fungsi gen, termasuk hilangnya fungsi gen. Gen kelas A meliputi APETALA1 (AP1) dan APETALA2 (AP2), gen kelas B

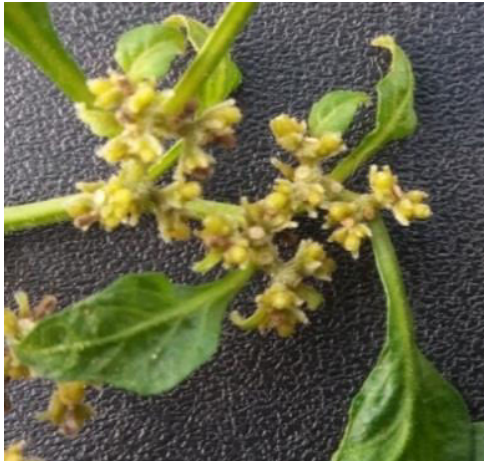

Gambar 3. Morfologi bunga diduga mutan.

meliputi APETALA3 (AP3) dan PISTILATA (P1) dan gen kelas C meliputi AGAMOUS (AG). Gen kelas A akan mengontrol pembentukan sepal pada lingkaran terluar. Gen kelas A dan B mengontrol pembentukan petal pada lingkaran ke dua, gen kelas B dan C mengontrol pembentukan stamen pada lingkaran ke tiga. Gen kelas $\mathrm{C}$ mengontrol pembentukan karpel pada lingkar ke empat [14]. Mutasi dapat menyebabkan perubahan pada struktur protein yang dikodekan atau penurunan atau kehilangan ekspresi [15] diduga mutasi oleh EMS menyebabkan hilangnya ekspresi gen yang mengontrol organ identitas yang menyebabkan terdapat bunga yang memiliki morfologi bunga berbeda dengan bunga normal.

Perkembangan tanaman yang cabai varietas bara pada konsentrasi EMS 0,5\%,1\%,1,5\% dan 2\% menunjukkan tidak semua tanaman cabai dapat berbunga, masing- masing konsentrasi EMS menunjukkan konsentrasi tanaman mampu berbunga yang berbeda beda (Tabel 1).

Tabel 1.

Pengaruh Pemberian EMS terhadap Presentase tanaman yang berbunga

\begin{tabular}{cc}
\hline $\begin{array}{c}\text { Konsentrasi } \\
(\%)\end{array}$ & $\begin{array}{c}\text { Persentase tanaman yang } \\
\text { berbunga } \\
(\%)\end{array}$ \\
\hline Kontrol & 100 \\
0,5 & 50 \\
1 & 100 \\
1,5 & 100 \\
2 & 16,67 \\
\hline \hline
\end{tabular}

Tanaman kontrol menghasilkan $100 \%$ tanaman dapat berbunga. EMS 0,5\% menghasilkan 50\% tanaman dapat berbunga. EMS $1 \%$ menghasilkan $100 \%$ tanaman dapat berbunga. EMS 1,5\% menghasilkan $100 \%$ tanaman dapat berbunga. EMS $2 \%$ menghasilakn $16,67 \%$ tanaman dapat berbunga.

Transisi dari pertumbuhan vegetatif menjadi pembungaan dikaitkan dengan pengaktifan gen identitas meristem. Produkproduk protein dari gen-gen ini adalah faktor transkripsi yang diperlukan untuk mengkonversi meristem vegetatif menjadi meristem bunga [16]. Adanya tanaman yang tidak dapat berbunga diduga karena adanya mutasi titik oleh EMS pada regulasi genetik dalam proses pembungaan. Mutasi titik dapat berupa missense mutation maupun nonsense mutation, missense mutation menyebabkan perubahan asam amino yang 
terbentuk sedangkan nonsense mutation menyebabkan sintesis protein terhenti [17] sehingga gen kehilangan ekspresi [15].

\section{UCAPAN TERIMA KASIH}

Penulis Andriyani mengucapkan terima kasih kepada Direktorat Pendidikan Tinggi, Departemen Pendidikan dan Kebudayaan Republik Indonesia yang telah memberikan dukungan finansial melalui Beasiswa Bidik Misi tahun 20132017.

\section{DAFTAR PUSTAKA}

[1] R. Rukamana, Usaha Tani Cabai Hibrida Sistem Mulsa Plastik. Yogyakarta: Kanisius, 1995.

[2] Pusat Data dan Sistem Informasi Pertanian, Komoditas Pertanian Subsektor Hortikultura Cabai. Pusat Data dan Sistem Informasi Pertanian, 2015.

[3] Biro Pusat Statistik Sulawesi Utara, "Berita Resmi Statistik No. No.50/08/71/Th.IX. Produksi Cabai Besar, Cabai Rawit, Dan Bawang Merah Tahun 2014," Sulawesi Utara, 2015.

[4] R. Rukmana, Usaha Tani Cabai Rawit. Yogyakarta: Kanisius, 2002.

[5] H. E. Pattee and H. T. Stalker, Advances in peanut science. New York:
American Peanut Research and Education Society, Inc, 1995.

[6] S. Mulyani, Anatomi Tumbuhan. Yogyakarta: Kanisius, 2006.

[7] B. S. Ahlowalia and M. Maluszynski, "Induced mutation-A new paradigm in plant breeding," J. Euphytica, vol. 118, pp. 167-173, 2001.

[8] Priyono and A. W. Susilo, "Respons Regenerasi InVitro Eksplant Sisik Mikro Kerk Lily (Lilium longiflorum T.) Terhadap Ethyl Metan Sulfonate (EMS)," J. Ilmu Dasar, vol. 3, pp. 74-79, 2002.

[9] E. Grotewold, Plant Fungction Genomics. America: Humana Press, 2013.

[10]C. VL. Mutagenesis, "Investigating the process and processing the outcome for crop improvement," J. Curr. Sci., vol. 89, pp. 353-359, 2005.

[11]L. Wang, B. Zhang, J. Li, X. Yang, and Ren, "Ethyl Metansulfonate (EMS) - Mediated Mutagenesis of Cucumber (Cucumis sativus L.), " $J$. Agric., vol. 5, pp. 716-721, 2014.

[12]M. Syukur, R. Yuniati, and E. Dermawan, Sukses Panen Cabai Tiap Hari. Jakarta: Penebar Swadaya.

[13]H. Lodish, A. Berk, L. Zipursky, P. Matsudaira, D. Baltimore, and D. J., Molecular Cell Biology, 4th ed. New York: WH Freeman.

[14]B. Jordan, The Molecular Biology and Biotechnology of Flowering, 2nd ed. United Kingdom: CABI Publishing, 2006.

[15]D. Marks, A. Marks, and C. Smith, Biokimia kedokteran dasar. Jakarta: EGC, 2000.

[16] Setiadi, Bertanam Cabai. Jakarta: Penebar Swadaya, 2006.

[17]N. Campbell and B. Reece, Biologi. 2: Erlangga, 2008. 